\title{
Integrated System in the Malaysian Education Paradigm: A Catalyst for a Holistic Personality Development
}

\author{
Nooraini Othman ${ }^{1} \&$ Khairul Azmi Mohamad ${ }^{2}$ \\ ${ }^{1}$ UTM Perdana School, Universiti Teknologi Malaysia Kuala Lumpur, Kuala Lumpur, Malaysia \\ ${ }^{2}$ Yayasan Ilmuwan, Kuala Lumpur, Malaysia \\ Correspondence: Nooraini Othman, UTM Perdana School, Universiti Teknologi Malaysia Kuala Lumpur, Jalan \\ Semarak, 54100 Kuala Lumpur, Malaysia. Tel: 603-2615-4371. E-mail: p-noraini@utm.my; \\ khairunnur69@yahoo.com
}

Received: December 12, 2013 Accepted: January 20, 2014 Online Published: April 22, 2014

doi:10.5539/ies.v7n5p8

URL: http://dx.doi.org/10.5539/ies.v7n5p8

\begin{abstract}
This paper intends to describe and analyse the process of education reform that has taken place in Malaysia. Islamisation plays a major role in such reform. The approach is innovative and novel in nature. Historically, Malaysia was under the British colony and the British left a strong impact in the education system. Naturally the position of Islam was not in the priority list. The post-Independent era witnessed a strong demand by the Muslims that Islam should be embedded firmly in the Malaysian education system. This paper also analyse some of the foundational issues relevant to the reform. The concept and methodology of this reform was finally translated in the form of learning institutions. It seeks to harmonise between the western and the Islamic traditions of knowledge. The success is far reaching and has a strong impact on human capital as well as knowledge society developments.
\end{abstract}

Keywords: Malaysian education system, education reform, Islamic education, integrated approach, holistic personality

\section{Introduction}

The Malaysian education system has been undergoing a tremendous foundational reform. One of the most important and leaving an indelible mark is the Islamisation programme. The intention is to place the Islamic educational values entrenched in the mainstream education system. The move is certainly historical but what is truly definitive is its holistic coverage and sound methodology. It is believed to be one the living models for the Muslim world in particular to view and emulate. Indeed it is a unique approach and novel in nature to find such innovative solution to the issue of dualism in the Malaysian education system. For the Muslims, to embed Islam as the core value in the education mainstream, they must strive hard and not to lose the vision. Muslims themselves must prove their worth in resolving the dichotomy in the education system brought about by the Western colonial master and to implant the Islamic value system.

Garaudy (1989) and Langgulung (2002) stated that it is crucial, in this, as in other domains, to avoid two errors: blind copying of the West and outright rejection of everything Western. Muslims should acquire Western science and technology selectively, creatively, and critically. Garaudy (1989) was of the opinion that, the major task confronting the Muslims today is to rediscover the majestic simplicity of the message of Islam and to present it to the new century.

Garaudy (1989) was further of the view that Muslims have to prove their ability to solve the problems that the West is incapable of solving. They need to discover new forms of growth and development, a culture that does not lead to human destruction but to the flowering of humanity. For this, it is of capital importance not to read the words of Allah in the Qur'an with the eyes of the "dead", that is to say, with the eyes of those who may have found the straight path but went no further than to solve the problems of their own time and localities. Muslims must read the Qur'an with eyes to discharge their responsibilities as the vicegerents of Allah on earth. Muslims must, in short, find answers to their own problems in light of the eternal message of the Qur'an. Accordingly in this relation, Azra (2011) promoted that Muslims must be able to develop theories that are based on Muslim social and cultural realities. It is thus imperative that educational transformation and innovative approach in 
education to be put well in place to realise such intention (Othman \& Mohamad, 2014). Locally in Malaysia, the seminal works of Al-Attas $(1993,1999)$ such as Islam and Secularism and The Concept of Education in Islam, should provide philosophical groundings for further analysis. Later scholars such as Baba (2000) and Hashim (2004) help to elucidate the subject matter further.

\section{Self-Criticism and Cause to Reform}

The Malaysia fourth Prime Minister, Dr. Mahathir Mohamad is a very strong personality who promoted and defended the effort of promoting Islam in the most practical manner. His argument is always that Islam should be promoted with full of wisdom. It should not be promoted on point of sword or engagement in any form of terrorism. It must aim towards civilisational glory. Muslim world must work towards being a truly civilised nation with its population being a truly civilised citizen.

Mohamad (1989) made self-criticism on the Muslims. He said that the last four centuries have done the Muslim ummah, little credit. Muslims do not reflect the essence of Islam which was once the pacesetter of humanity. The future must reflect a new approach; Muslims must have clearly crystallized ideas and well-articulated goals. He asserted that Muslims can carry out orderly and constructive work only when the planning is thorough and labour towards recognised and acceptable goals. Unfortunately, the vast majority of Muslims, including intellectuals and those involved in the Islamic movements, have overlooked what to most builders is obvious. They know they must go somewhere but they do not know exactly where to go. Muslims must therefore plan for the future and this means the need to analyse the past and take stock of the present.

It is clear that man's survival is dependent on new patterns of mutual partnership and cooperation, interdependence and symbiosis. This will not be possible without long-term planning for the next twenty to forty years. Muslims also need to understand Islam within the context of the contemporary world, with the changed conditions of life. Muslims cannot recreate the world of the early years of Islam. The changes that have occurred in recent decades are fundamentally the biggest changes human society has ever experienced, but in practical and intellectual terms, Muslims have not been able even to conceive of how to reorganize their political, social and economic lives to take in the changes that have taken place. Muslims should reorganize their political, social and economic lives in a way that fully incorporates the injunctions of Islam to ensure that a socially healthy, politically coherent, and economically efficient and vigorous ummah will emerge, able to face all challenges.

Examination of other injunctions of Islam convinces us of the same conclusions. One may ask what significance does all this have? If Muslims are unable to understand these injunctions of Islam with reference to contemporary reality, they have failed to understand Islam itself; they fail to understand the social conduct desired of them by Allah if they fail to operationalise the injunctions with reference to contemporary reality, and thus will not be able to plan effectively for the future.

He admitted that this is a painful admission. And this is the root cause of the present predicament of Muslims. Not only failed to live up to Islam, but also, to a large extent, failed to appreciate its universality. It follows therefore that to understand the underlying dynamic relevance of the injunctions of Islam in contemporary society and to work out the process of their implication in practice is an acute spiritual need of the Muslim ummah.

In that direction he said, for Muslim civilisation to achieve its destiny and experience a second upturn, a balanced approach to Islam and a certain amount of self-criticism is prerequisite. Muslims must learn to be honest with themselves. They need to apply this balanced approach to this world and to the hereafter. The concept of the hereafter was given to man to broaden his outlook and not to make him blind to his immediate environment. Muslims must seek goodness, both in this world and the next. Modern scholars must therefore be neither too preoccupied with this world nor exclusively entranced by the next. Both must influence their scholarly efforts and exhortations.

He further stressed that there is no escape from planning for the future. If Muslims really want an Islamic social order, then they must examine every aspect of modern life from the perspective of Islam and make necessary corrections. The comprehensive relevance of Islam to everything has to be established on a concrete level and many questions must be researched and examined. A practical blueprint for the implementation of Islamic systems needs to be worked out taking into account the practical realities of today's world. On the direction, he said the followings.

Ibn Khaldun uses the word umran for a dynamic, thriving, operational civilization.

The Muslim world today needs such a viable plan as an alternative and to present to the Muslim ummah convincing visions of the Muslim civilization of the future. 
Muslim academicians should master all the modern disciplines, understand them completely and achieve an absolute command of all that they have to offer. This is, however, only the first prerequisite. Then they should integrate the new knowledge into the corpus of the Islamic legacy by eliminating, amending, reinterpreting and adapting its components according to the world view of Islam and its values. The exact relevance of Islam to the philosophy of the disciplines should be determined. A new way in which the reformed disciplines can serve the ideas of Islam should be adopted. Finally, by their example as pioneers, they should teach the new generation of Muslims knowledge even further forward, discover new layers of the patterns created by Allah and a new ordering of thought in Islamic disciplines deriving from tawhid, and establish new paths for making His will and commandments realized in history.

In developing such a fresh understanding of Islam, in adjusting to change, we need a number of intellectual tools. We need to develop a tradition of Muslim scholarship that incorporates modern methods of study and research into the best techniques of traditional scholarship.

\section{Reorientation of Education}

Abul-Fadl (1995) in her work Toward Global Cultural Renewal: Modernity and the Episteme of Transcendence wrote that Islamisation constitutes a major force of renovation upon the contemporary world scene. It was born as a wide-ranging cultural movement which essentially sought to recover the vitality of the community by recovering the vitality of its heritage. She further notes that Islamisation provides a credible and viable response to our vital needs today. The pervasive cultural disarray characteristics of our times act as a corrosive force on contemporary civilisation. The credibility and viability of this message to the immediate context as an instrument of rehabilitation and renewal will need to be developed by a scholarship capable of bridging the gap between cultures for the benefit of all. Islamisation, then, constitutes that process of reforming and revitalising the current underlying structures of thought and perception by means of their exposure to a radical critique in the light of an integrated set of cognitive, affective and symbolic values derived from the Islamic tradition.

Al-Alwani (1995) stressed that, as we speak of Islamisation, the term should not be confined to a hard and fast definition. The idea has always been understood as an intellectual and methodological outlook, rather than as an academic field, or specialisation, or ideology, or new sect. It has always attempted to view issues from the perspectives of reform, inquiry, and self-discovery, without any preconceptions, doctrinal or temporal constraints, or limitations on its intellectual horizons.

He further asserted that it is not blind to the fact that it may take decades before the methodological and epistemological issues covered are clarified in any definitive manner. They should be understood as landmarks on the road to the sort of learning which may assist in reforming the Muslim mind, so that the ummah (Muslim community-translation added by the present authors) may address its own crisis of thought and participate actively in the attempt to deal with the crisis of thought affecting the rest of the world.

Abu-Sulayman (1994) accordingly outlines the ways where Muslims could initiate reform to knowledge, culture, and civilisation in order to steer the Islamic movement in the right direction, to invigorate the Muslim character, and to formulate plans for Islamic $d a^{\prime}$ wah (calls to the teachings of Islam-translation added by the present authors). His suggestions go in the followings:

First, rectify the relationship between divine revelation and reason as manifested in our line of thinking.

Second, redefine knowledge in a way that leaves no ambiguity about concepts such as ijtihad (independent reasoning exerted by a suitably qualified Muslim scholar of jurisprudence-translation added by the present authors) and roles such as that of the faqih (a scholar of Islamic jurisprudence-translation added by the present authors). In this respect, there must be a clear distinction drawn between ijtihad and ifta (a formal legal opinion issued by a mufti that is a qualified scholar of jurisprudence, based on a question posed to him-translation added by the present authors) in the light of the current trends in Islamic thought.

Third, reorganise and reorient the methodology of Islamic education and instruction in order to put an end to the confused dualism that divides knowledge into intellectual, social, religious, and legal categories, thereby creating further dualism in the leadership.

He further argued that there also exist in the Muslim world an imported secular knowledge which dominates every aspect of life, and whose advocates respond thoughtlessly and imitate blindly the trends and developments 
of the age. This secularism is perpetuated and popularised by institutions, universities and organisations in various Islamic countries.

He further said that the two categories of knowledge form a tree which is unable to grow, because the first category lacks the essential dynamism to foster growth and the second is alien to the Muslims, their land, goals, and objectives. For this reason, when one talks about reforming and reconstructing the perspectives of Islamic knowledge and culture, one has in mind the initiation of a revival that should make them fit once again for production and growth. But that goal cannot be achieved without reconstructing and reorienting the programs of education and instruction. The hope for and the possibility of uprooting the forms of dualism in knowledge at the leadership level lies in providing technically able and Islamically committed cadres who are well versed in simplified and purposefully categorised Islamic teachings.

Initially, each field of specialization must include in its curriculum a sufficient number of texts of religious knowledge to mould and guide the mentality of the learner. Next, it is imperative that every aspect of the curriculum reflect the objectives and values of the teachings of Islam in a harmoniously comprehensive manner so as not to lose the essential unity of the nature of Islamic knowledge and culture. Only then can the Ummah claim to possess knowledge that corresponds to Islamic objectives.

The reorientation of education and instruction toward a purely Islamic style for the fulfilment of Islamic objectives would include methodology, professional commitment, and social participation in accordance with what is proper for each field and what is required by the Muslim Ummah.

\section{Integration Process}

Al-Alwani (1989) in his analysis said that the contemporary theory of knowledge affirms that the only possible source of scientific knowledge is the tangible universe. The Islamic theory of scientific knowledge, on the other hand, stresses that knowledge has two sources: Revelation and the tangible universe. Revelation is the source of absolute facts and truth about which there is no doubt whatsoever and is not subjected to relativity. Revelation is contained in the Quran which is the word of Allah revealed to the prophet.

He was of the view that the current system of education in the Muslim world has failed to instil any such belief, sound vision, standards or motives in the Muslim. As a result of this failure, the aim of education for the Muslim, at various levels, is to obtain decent employment with a decent income. Materialism has become widespread among the educated who have lost any sense of a clear purpose in life. Academic syllabi have failed to establish a sound purpose in the Muslim conscience. The only way to achieve this is to establish a sound Islamic belief (aqidah) and to instil a sound Islamic vision in the hearts and minds of Muslim youth. Muslims must use all available means and resources to nurture and develop this belief and vision in order to achieve a sense of belonging to the Muslim ummah. Muslims must make this belief the motivation and the inspiration for our thoughts and feelings.

The proposed cultural strategy must firmly establish Islam and its vision, not through limited classes on "religion", but throughout the entire education system. This should be done through re-organising the education system in all Muslim countries and by removing the negative influences of the disparity between religious, secular and military education. We do not want to abolish variety and specialisation in learning; what we want is to end the segmentation of knowledge.

This could be achieved by integrating all existing systems and creating one single system based on the teachings, spirit and vision of Islam. The new education system, its syllabi and methods, and those responsible for it, should all be infused with the principles and aims of Islam.

In developing an Islamic alternative in thought and knowledge special attention must be given to the study of Islamic civilisation. The study of Islamic civilisation, according to a proper, methodical syllabus, to which a number of selected Islamic thinkers, educationists and psychologists have contributed, is considered to be one of the most important means of creating the individual's feeling of belonging to the ummah, and enabling him to understand the spirit which motivated our forefathers to make their achievements in the fields of art and sciences, as well as in political, social and economic thought.

Our new educational strategy must include the planning of a course of study explaining the bases, values, sources and aims of Islam as a source of thought, culture and civilisation.

Hassan (1994) explained, especially in the context of Malaysia that the process of Islamisation has to be understood in the following terms:

First, it is a process of realising the unitive Islamic world-view which does not recognise the separation of life 
into water-tight realms-the realm of God and the realm of man, or the separation of material concerns from spiritual values. Second, it is a process of legitimate restoration of the central place of Islam as a comprehensive way of life of the Muslim populace before the advent of British rule. This is part of the process of rediscovering Islamic roots and identity after undergoing the impact of Westernising and secularising modernisation under the British rule. Third, it is a process of desecularisation of Malaysian culture, government, law, economy, and education in the post-independence era. This is also the experience of all Muslim countries which had been living under the dominance of Western cultural and political colonialism and imperialism.

Fourth, it is a process of correcting the concept and implementation of national development policies, which under the influence of secularist ideas in the sixties and seventies focused mainly on economic and physical developments. The Islamic doctrine of integrated and holistic human development which is based on the unity of body, mind and soul as well as the unity of life in this world and life in the hereafter was the driving force behind this process. In the eighties and early nineties the idea of holistic and integral human development has been acknowledged by the government, thanks to the efforts of internal forces of Islamic awareness as well as the external forces of holistic development and de-secularisation.

He further observed that it was therefore quite natural for Muslim groups and scholars in the post-independence period to demand for the implementation of Islamic education principles within the national system. The system which was inherited from the British period was gradually modified to include the subjects of Islamic religious knowledge in the government primary as well as secondary schools.

The establishment of the International Islamic University Malaysia by Mahathir's government in 1983 was the culmination the educational aspirations of the Muslims in Malaysia. Its vision of integrated knowledge and mission of producing professionals imbued with Islamic values and principles are being pursued without any obstacle from the government.

\section{Holistic Personality Development}

Islamisation in the sector of education has been taking place stretching over all levels of studies. It is an effort for the rebirth of a civilisational glory. Being historically romantic of the previous successful generations will not help the process of building a new chapter of the Muslim civilisation. The challenge is to translate the teachings of Islam in the sphere of Muslim education system in the modern and contemporary context suitable for the millennia. Malaysia certainly provided a strong and practical model to be studied and contextually adjusted to suit a different culture and environment of a given country who wish to emulate such system. Knowledge stands at the fore front of human well-being. The reform of the Malaysian education system sets an impetus towards the development of an added value knowledge society.

Al-Roubaie (2012) made some important observations. Recent trends in development studies have identified knowledge as a key driver in job creation, wealth distribution and socio-economic transformation. In this age of globalization, knowledge is a global good which can be acquired and used by individuals, enterprises and nations. In particular, the developing countries are in an advantage position to make use of the global knowledge as a substitute for locally produced knowledge to close the knowledge gap. Countries with limited physical and human capital resources can accelerate the process of development through access to global knowledge, skills and technology. Globalization has improved factor mobility, increase global trade and permitted technology transfer. Meeting the challenges of globalization entails building institutional infrastructure, stock of human capital and technological learning to facilitate knowledge absorption and adaptation of foreign technologies. Building such capacity allows Muslim countries to accelerate the process of modernisation by surpassing several stages in their development.

With the notable exception of Malaysia, most Muslim countries are still unable to meet the challenges of globalization and take advantage of the new economy. Unfortunately, Muslim countries are not investing enough in science and technology, skills, digital technologies, innovation and lifelong learning. Widening of the knowledge and digital gaps between Muslim countries and the rest of the world could engender serious consequences by rendering Muslim countries inadequately equipped to deepen global integration, enhance competitiveness, foster economic growth, promote innovation and build knowledge societies.

The Muslim mind must be re-oriented to exercise greater interest in the building a knowledge society through education, skills, incentives, rewards and management. Creative and productive ideas in the mind of people can be exploited to germinate the building blocks of a knowledge society. Denying people the right to participate in decision-making not only undermines the human contribution to development, but also represents a substantial waste of the most important resource of society. In the knowledge society, people are the real resources which reflect the importance of investment in human capital to enhance creativity and increase productivity. 
The students developed by this reformed system, particularly at the higher learning institution such as the International Islamic University Malaysia become a holistic personality who intellectually masters the knowledge that comes from the Western world as well as of the Islamic tradition. The place becomes the centre of intellectual meetings where the professors come from many parts of the world, sharing their expertise and wisdoms. In the same time, students from all over the world can benefit the richness of this environment. It becomes the new Baitul Hikmah (House of Wisdom) of the previous years in Baghdad, albeit, in the new age and in the modern settings.

The Malaysian experience in developing such system is indeed valuable to other Muslim nations to examine and understand. The process took a long time to mature and it is still ongoing. Apart from intellectual initiatives, political will play a very vital role in making the agenda a success. The Malaysisn experience witnessed that the prime minister of the country becomes the prime mover and catalyst of such reform to take place.

\section{Conclusion}

According to Latif (2007) civilisation should mean "perfecting civil life or of the relations of men among themselves". The test is the quality of perfection attained; and the higher the quality, the superior the civilisation. This quality is determined by two factors; or rather it is a mixture of two ingredients capable of blending into each other. First, if civil life is to be perfected, it must represent organised social relations based, on the one hand, on increasing production of the means of giving strength and happiness to society, and, on the other, on an equitable distribution amongst individuals of the strength and happiness so produced. This is a primary condition of civilisation. There is another condition which should be fulfilled. Civilisation must also represent a process of perfection of the individual himself, of his faculties, his sentiments, his ideas making organised civil life humane or such as may glorify human nature. In other words, civilisation must always manifest two symptoms-progress of society, and progress of humanity.

A society may be fully developed and its distribution of wealth within its own circle quite equitable; but it may prove a curse to humanity at large all the same. Hence it is that we insist, in every civilisation, on the presence of some degree of this second quality which makes for the progress of humanity. And the greater the degree in which this quality blends with the other quality, the higher the station it occupies among civilisations.

If a civilisation is to be truly noble, truly great, it must, for its second quality, incorporate in its texture a culture whose foundations lie deep in the eternal and all-pervasive spiritual law of life which has struggled through ages to mould mankind into one entity. For it is only on such a basis of organised life, and through such a culture, that a true civilisation can live and thrive.

\section{References}

Abul-Fadl, M. M. (1995). Toward Global Cultural Renewal: Modernity and the Episteme of Transcendence. Virginia and London: International Institute of Islamic Thought.

Abu-Sulayman, A. A. (1994). Islamisation: Reforming Contemporary Knowledge. London: International Institute of Islamic Thought.

Al-Alwani, T. J. (1989). Outlines of a Cultural Strategy. London: International Institute of Islamic Thought.

Al-Alwani, T. J. (1995). The Islamization of Knowledge: Yesterday and Today. Virginia and London: International Institute of Islamic Thought.

Al-Attas, S. M. N. (1993). Islam and Secularism. Kuala Lumpur: ISTAC.

Al-Attas, S. M. N. (1999). The Concept of Education in Islam: A Framework for an Islamic Philosophy of Education. Kuala Lumpur: ISTAC.

Al-Roubaie, A. (2012). Globalization of Knowledge: Re-Orienting the Muslim Mind for Building Knowledge Societies in The Muslim World. International Conference on Re-Orienting The Muslim Mind: Charting The Future. Kuala Lumpur: Institute of Islamic Understanding Malaysia.

Andersen, L. E. (2001). Low Social Mobility in Bolivia: Causes and Consequences for Development. Germany: Kiel Institute of World Economics.

Azra, A. (2011). From IAIN to UIN: Islamic Studies in Indonesia. In K. Bustamam-Ahmad, \& P. Jory (Eds.), Islamic Studies and Islamic Education in Contemporary Southeast Asia. Kuala Lumpur: Yayasan Ilmuwan.

Baba, S. (2000). Integrated Knowledge in the Tawhidic Curriculum: Muslim Education Quarterly. Cambridge: The Islamic Academy.

Garaudy, R. (1989). The Balance Sheet of Western Philosophy in This Century. In International Institute of 
Islamic Thought (Ed.), Toward Islamization of Disciplines. Virginia: International Institute of Islamic Thought.

Hashim, R. (2004). Educational Dualism in Malaysia: Implications for Theory and Practice. Kuala Lumpur: The Other Press.

Hassan, M. K. (1994). The Influence of Islam on Education and Family in Malaysia. In S. O. Alhabshi, \& S. O. S. Agil (Eds.), The Role and Influence of Religion in Society. Kuala Lumpur: Institute of Islamic Understanding Malaysia.

Langgulung, H. (2002). A Psycho-Pedagogical Approach to Islamisation of Knowledge. Kuala Lumpur: International Islamic University Malaysia.

Latif, S. A. (2007). The Mind Al-Quran Builds. Kuala Lumpur: Islamic Book Trust.

Mohamad, M. (1989). Islamization of Knowledge and the Future of the Ummah. In International Institute of Islamic Thought (Ed.), Toward Islamization of Disciplines. Virginia: International Institute of Islamic Thought.

Othman, N., \& Mohamad, K. A. (2014). Thinking Skill Education and Transformational Progress in Malaysia. International Education Studies, 7(4), 27-32. http://dx.doi.org/10.5539/ies.v7n4p27

\section{Copyrights}

Copyright for this article is retained by the author(s), with first publication rights granted to the journal.

This is an open-access article distributed under the terms and conditions of the Creative Commons Attribution license (http://creativecommons.org/licenses/by/3.0/). 